Jul 1st, 12:00 AM

\title{
Simulation of Resilience of an Insurance System to Flood Risk
}

\author{
F. Grelot
}

Olivier Barreteau

Follow this and additional works at: https://scholarsarchive.byu.edu/iemssconference

Grelot, F. and Barreteau, Olivier, "Simulation of Resilience of an Insurance System to Flood Risk" (2012). International Congress on Environmental Modelling and Software. 128.

https://scholarsarchive.byu.edu/iemssconference/2012/Stream-B/128

This Event is brought to you for free and open access by the Civil and Environmental Engineering at BYU ScholarsArchive. It has been accepted for inclusion in International Congress on Environmental Modelling and Software by an authorized administrator of BYU ScholarsArchive. For more information, please contact scholarsarchive@byu.edu, ellen_amatangelo@byu.edu. 


\title{
Simulation of Resilience of an Insurance System to Flood Risk
}

\author{
F. Grelot $^{\mathrm{a}}$, O. Barreteau ${ }^{\mathrm{b}}$ \\ a UMR G-EAU IRSTEA, 361 rue JF Breton BP 5095, 34196 Montpellier, France \\ (pauline.bremond@irstea.fr, fredreric.grelot@irstea.fr)
}

\begin{abstract}
The aim of this communication is to discuss the benefit of agent-based modelling to characterize the resilience of French insurance system to flood risk to extreme events. We first characterize the "Cat Nat" system, the French system to manage recovery costs after major natural disasters. We then described the CatNatABM model. The main purpose of this model is to explore feedbacks between the dynamics of households settlement and the viability of "Cat Nat" system. This behavior based model is meant "as simple as suitable" to capture main feedbacks of the system, with the purpose of enriching it gradually. Outputs of the model are dynamic, which allows to analyse the influence of eligible realisation of flood chronicles. In this paper, we focus on comparison between a benchmark state with no "Cat Nat" system and a insurance state with a "Cat Nat" system without regulation, to explore the conditions under which perverse effects of insurance may occur.
\end{abstract}

Keywords: Insurance, Shock, Path Dependency, Flood Risk, Modelling

\section{INTRODUCTION}

In many countries, land use control and insurance system are two instruments that are mixed to deal with securing people against flood, both from physical and economic damage. The implementation of those instruments by some collectivity (more often the national one), may suffer from lobbying and ad hoc negotiation of agents having interests in land use development. Even if the collectivity may be tempted to listen lobbyists' arguments, it must deal with the irreversibility of settling, and the difficulty to change the rules. Efficiency and side effects of these coupled instruments has not been systematically explored. This gap becomes increasingly problematic when considering potential upcoming global changes, including climate and demography.

This paper proposes an agent based model as a testbed for institutional flood protection instruments. We first present the current institutional instruments in the case of France, then we describe the CatNatABM model and detail results of exploring systematically simulation outcomes on basic scenarios.

\section{The French mix : "Cat Nat" Reinsurance system and zoning}

The "Cat Nat" is the French system to manage recovery costs after major natural disasters (Grislain-Letrémy and Peinturier [2010]). This system was introduced by a law in 1982 based on insurance and land use regulation. Insurance companies have to insure particular natural hazards (including flood, earthquake, volcano eruption) under conditions fixed by French State. The State fixes a rate on property insurance premiums, 
independent of risk exposure, which therefore introduced solidarity at national level. The system relies on a "Cat Nat" fund, managed by the CCR, a reinsurance agency controlled by French State. This fund is supplied from insurance companies which decide to be reinsured by the CCR, which happens in most cases. The fund is used to compensate insurance companies' losses, it has unlimited warranty from the State. The law also created tools to control land use in natural hazard prone areas (called PPR). French State tries to manage the system to limit the use of its warranty. Since its creation, to preserve the equilibrium of the "Cat Nat" fund, the rate on property insurance premiums has more than doubled to adapt to demographic changes and to the occurrence of some extreme events.

Considering that the objective of this system is to cover damage of natural hazard, this system is perceived as efficient. Nevertheless it has been subject to some critics. According to Latruffe and Picard [2005], it could introduce some lack of responsibility for agents choosing to settle in risk prone area. Within a context of global changes (climate and demography related), the viability of the fund, and therefore the resilience of the whole system, is at stake. Consequently, some authors have proposed to modulate the rate on property premiums and thus the degree of solidarity according to risk exposure (Picard [2008]) or to the existence of PPR (Scarwell et al. [2010]). In fact, this decision is more political than purely technical.

Implementation of those public policies is constrained by the social acceptability on both the variations and the values of key parameters, namely the level of levies (rate on insurance premiums) and the limit of land use regulation. Both those parameters are set at a national level, even if local collectivities argue to have some flexibility on the limit of land use regulation. The influence of those parameters may be seen such as to mitigate the damage induced by natural hazard. We consider that they are rather levers to deal with the durability of a system which principal objective is to compensate damage suffered by inhabitants. Therefore, different regime may be possible: a high level of damage (low regulation) with a high level of levies, a low level of damage (high regulation) with a low level of levies. The possibility to switch from one regime to another, or to fit somewhere in between is a political choice, that is time to time discussed in the political field ${ }^{1}$.

There exist few agent-based modelling dealing with impacts of policies of regulation and their implementation constraints or advantages. Nevertheless, some works concern simulation of landscape dynamic in a cellular modelling framework (Werner and McNamara [2007]), some focus on market interactions, introducing flood risk as negative externality (Filatova et al. [2009]), other consider aesthetic quality induced by greenbelts (Brown et al. [2004]). To describe the evolution of such a territory exposed to flood risk, we propose a simulator compounded of agents who settle in this territory. In former discussions (Barreteau and Grelot [2011]), we have shown that the level of regulation is not adapted for a dynamic regulation of the "Cat Nat" fund, this regulation shall be made by adjusting the level of levies. In this paper, we are more interested in comparing two states: a benchmark state where no "Cat Nat" system is implemented, and an insurance state where the "Cat Nat" system is implemented with no regulation. This comparison may give some insights on the perverse effects of the insurance system as described on the litterature.

\footnotetext{
${ }^{1}$ For example, this excerpt of a Nicolas Sakorzy speech, 29th of avril 2009, is meaningful: "The issue is the regulation. To free the supply, we have to deregulate, [...], allow the construction in flood prone area for building adapted to environment and risk [....]"
} 


\section{CatNatABM Model}

\subsection{Structure of the model}

This model aims at capturing main features of population vulnerability to flood through its settlement and migration, at national scale. Therefore we chose to design a virtual area, as a cell automaton supposed to represent France, made of 5 sub-areas. These sub-areas are independent regarding flood risk and migration (no trade-offs between sub-areas for migrants) but share the same policy instruments. Since an initial version of this model showed that a policy based on zoning only is not adaptive (Barreteau and Grelot [2011]), we focus here on the insurance instrument. Connection between sub areas comes then through sharing a single insurance fund and the same tax rate.

Each sub area has the same size, with $20 \%$ being flood prone and $80 \%$ out of reach of floods. Space within sub areas is organized through distance to a river since we assume flood risk due to river overflow. Each sub area has the same probability of being flooded.

Independent flood events are generated at each yearly time step for each sub area. Population dynamics is dependent on an initial settlement in each sub area. This initial settlement is a gaussian distribution occupying 1000 cells in each subarea around a centre, whose distance to the river is a parameter of simulation. Each time step $0.5 \%$ of the population of each sub area (taken randomly) leaves the area while new households settle in. Number of newcomers is a ratio of current population given as a parameter of the model. Each new household comes in with preference for being at a given distance to the river. This preference is determined by a random number drawn in 10, 1] compared to distribution of attractivity of cells according to their distance to the river. Attractivity of cells for a given household hh at distance $i$ of the river is the sum of three components: attractivity for the river considered as a positive amenity, attractivity for already populated area and repulsion for area with ruined houses.

Attractivity for the river is given by: hh.river Attractivity $\times$ terr.distribWater Activity $(i)$, where hh.river Attractivity $\in[0,1]$ is a weight characterizing the consequence of the river amenity for newcomers settlement choice and terr.distribWaterActivity $(i)$ gives the potential of attraction of the river at distance $i$. We considered this attraction proportional to: $e^{-\frac{i}{\text { prof.Atractivity }}}$ with a sum normalized to 1. prof.Attractivity is a parameter of the sub area, set to 10 in the simulations.

Attractivity for already populated areas is given by: (1 - hh.river Attractivity + hh.repulsionFactor $) \times$ terr.distribProxActivity $(i)$, where terr.distribProxActivity $(i)$ gives the potential of attraction of cells at distance $i$ of the river, computed as the sum of cells occupied by a households at this distance, as well as at distance $i-1$ and distance $i+1$. The sum across all possible distances is normalized to 1 . This potential is then weighted for each $h h$ with an attraction weight considered as the sum of (a) the complementary to 1 of river Attractivity and (b) a weight of repulsion towards emptiness, repulsionFactor $\in[0,1]$. This last weight stands for a need of a feeling of security of newcomers.

Repulsion for area with ruined houses aims at capturing a stronger repulsion for cells occupied by a house that has been ruined by a flood and not repaired. It is given by: hh.repulsionFactor $\times$ terr.distribRepulsion $(i)$, where the same weight of repulsion towards emptiness is used together with a potential of repulsion of a cell at distance $i$ given by terr.distribRepulsion $(i)$ that is the ratio between the number of ruin cells and the squared roots of the number of built cells (whatever the state of the building). We chose this computation to capture first the impact of density of ruins rather and in a sec- 
ond order the number of ruins. As for the previous ones, the sum of this distribution of repulsion potential is normalized to 1 .

Besides households, a regulating agent is implemented and activated in scenarios with the insurance system, Regulator, whose role is to collect fees for the insurance fund and to take in charge reparation of any damages caused to existing buildings by a flood.

There is only one for the whole area. This agent aims at keeping the fund level between 0 and a maximum, which is set at three times the collected fees. All the houses are considered the same so with a single amount of damages in case of floods, set as potentialDamageAmount. Each time step this agent collects the fee from all households at the same amount: reg.feeLevel $\times$ potentialDamageAmount. reg.feeLevel can be adapted by Regulator in order to keep the fund in the objective interval, as a mean value over a time lapse, given as an attribute of Regulator, being an additional parameter, horizon.

\subsection{Dynamics of simulation}

Dynamics is given according to two institutional scenarios, one with a common insurance fund, one with no regulation, one climate scenario and scenarios of behavioural patterns for population. Climate scenarios are made of a sequence of flood extension for each sub area, fitting current probabilities of flood in France. Figure 1 shows the aggregation of these flood extensions for three climate scenarios.

At each time step, simulation generates new households settling in each subarea according to the parameters and probabilities described previously. Then occurrence of independent flood extension is generated. Consequences of these floods are either expenses for the insurance fund according to the number of flooded houses or transformation of existing houses in a ruin state if there is no insurance fund. Then households who have been flooded react, according to an additional parameter floodTolerance $\in[0,1]$.

For each $h h$, a random number taken from $] 0,1]$ is compared to this parameter. If this random number is bigger, the $h h$ leaves the area. If it is smaller the hh stays and repairs the house if the insurance fund has not done so yet.

\subsection{Dynamics of simulation}

The model described above simulates several state variables of the system. These include the position of built areas for each sub area as well as for the whole system, population (total, by sub areas and in areas submitted to flood areas with a given frequency - such as decennial flood area). An indication of intensity of damages is also given with number of ruins and number of flooded houses. For simulation with the insurance scenario, we observe also economic indicators: budget level of the insurance fund, benefits of the fund and fee level. Position of built area is actually computed as the mean distance to the river of cells occupied by a house inhabitated.

For the sake of demonstration of the potential of this testbed model, we will not go in detail in this communication in all indicators. We will focus on impact of various scenarios on mean position of built area, indicator centering (figure 3), global population (figure 2) and fee level (figure 4). The centering indicator is used as a proxy to the exposure of the territory: the lower it is, the more the population is closed to the river and thus exposed to flood. In the implementation we present, the limit of the flood prone area is fixed at value 100. 
Sequence 2
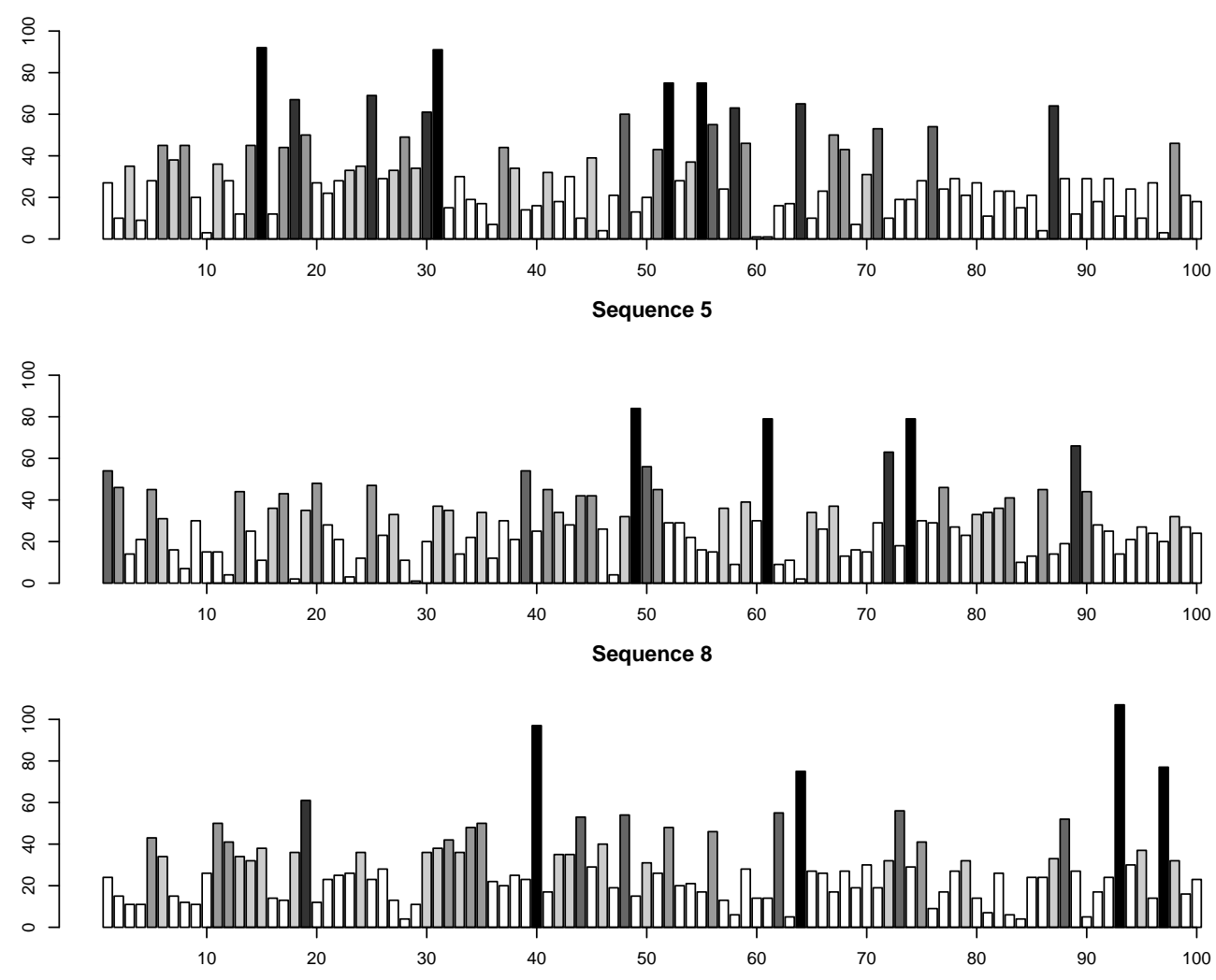

Figure 1: Characterization of flood sequences

\section{Results AND discussion}

\subsection{Suitability of the model}

This version of the model entails exploring the impact of scenarios. We performed a thorough analysis of the model behavior to check its consistency: for each feature observed on simulation outcomes we came back to the causes that could explain them in the model, in order to eliminate bugs and other artifacts.

The model is then able to tell stories that fit what take place in reality, even though its very virtual character as far as space is concerned. As a proof of concept of model relevance for this use, we provide in following subsections three examples of discussions. One is related with path dependency on built area positions and population, another with impacts of insurance introduction, while the last one is related to fee level realism.

\subsection{Path dependency}

Exploration across the climate scenarios shows some path dependency. Figure 2 provides evolution of population and built area positions for scenarios with insurance and without insurance (benchmark). It appears that at least for benchmark scenarios we see 
some convergence of centering. This centering is different according to climate scenarios and the sequence of floods. Early occurrence of major floods entails a faster relocation of built area further from the river. With later ones, this relocation is less important due to a higher inertia with already settled population. Population level is less dependent to this path dependency: convergence is similar, at least with benchmark scenarios.

\subsection{Perverse effet of insurance introduction}

Introduction of an insurance system generates a perverse effect that can be seen on figure 3 that features the evolution of position of built areas relatively to the river. There are fewer feedbacks of flood events on population behavioral patterns (figure 2). Therefore we observe that location of built area getting closer to the river when there is an insurance system. This is due to the absence of landmarks such as the ruins left by flood events.

This impact is particularly important when flood tolerance is higher. Further one expected consequence of insurance system is to make people more tolerant to flood since they don't have any more financial costs besides the inconvenience of being flooded. This makes a double effect of insurance system: in order to decrease consequence for inhabitants we make them more tolerant and the area is hence more attractive.

As a consequence, a way forward to explore besides the insurance policy could be leaving landmarks in frequently flooded area showing the consequences of flood in order to make them repulsive for newcomers to settle.

\subsection{Fee level realism}

Figure 4 provides evolution of fee level. We can see that even though climate scenarios is clearly impacting fee level with reactions to major events in order for the fund to recover, mean value of the fee level is not impacted by the sequence of events nor their timing. However there is a clear division according to the assumption on population attitudes. Whenever the institutional setting enables fully tolerant behavioral patterns ( floodToleranceLevel $=1$ ), the fee level is much higher, while when it is below 1 (equal to 0 or 0.5$)$

it can stay at smaller and comparable level. It looks like there is a threshold effect of flood tolerance level on the fee level. This is due to the fact that people stay in frequently flooded areas, attracting newcomers to join them, and thus increasing potential costs. Even with initial settings further from the river, fee level is increasing steadily. On the contrary, it is enough that some people leave the area when they are flooded to make highly flooded area less attractive, so that the insurance fund can stabilize at lower level. The high level that is reached when flood tolerance level raises question of realism since it would probably not be acceptable and generate outing of inhabitants out of major flood areas. This is one reason for introduction of zoning as it is done by policy makers.

\section{Perspectives}

We have shown that this ABM can serve as a testbed for insurance policy. We need now to go further in several directions, in order to make narratives it can produce more thoughtful for policy makers. Thanks to the initial simulations presented here, we identify three main directions: realism of the institutional setting; refining exploration in some part of the parameter space including heterogeneity among subareas; impact of climate 
change and uncertainty on climate.

\section{REFERENCES}

Barreteau, O. and F. Grelot. Réassurance des catastrophes naturelles et dynamique de population en zone inondable : simulation exploratoire de politiques de régulation. In MASHS 2011, France, Marseille, June 23-24 2011. GREQAM.

Brown, D. G., S. E. Page, R. Riolo, and W. Rand. Agent-based and analytical modeling to evaluate the effectiveness of greenbelts. Environmental Modelling and Software, 19 (12):1097 - 1109, 2004.

Filatova, T., A. van der Veen, and D. C. Parker. Land market interactions between heterogeneous agents in a heterogeneous landscape-tracing the macro-scale effects of individual trade-offs between environmental amenities and disamenities. Canadian Journal of Agricultural Economics, 57:431-457, 2009.

Grislain-Letrémy, C. and C. Peinturier. Le régime d'assurance des catastrophes naturelles en france métropolitaine entre 1995 et 2006 . Études \& documents $n^{\circ}: 22$, Conseil Général du Développement Durable, Mai 2010.

Latruffe, L. and P. Picard. Assurance des catastrophes naturelles : faut-il choisir entre prévention et solidarité ? Les Annales d'Économie et de Statistiques, 78:33-56, 2005.

Picard, P. Natural disaster insurance and the equity-efficiency trade-off. Journal of Risk and Insurance, 75(1):17-38, 2008.

Scarwell, H.-J., P.-G. Salvador, and G. Schmitt. Prévention du risque inondation par ruissellement en milieu urbain: l'exemple de la métropole lilloise. Bulletin de l'Association de géographes français, 87(4):468-486, 2010.

Werner, B. and D. McNamara. Dynamics of coupled human-landscape systems. Geomorphology, 91(3-4):393-407, 2007. 

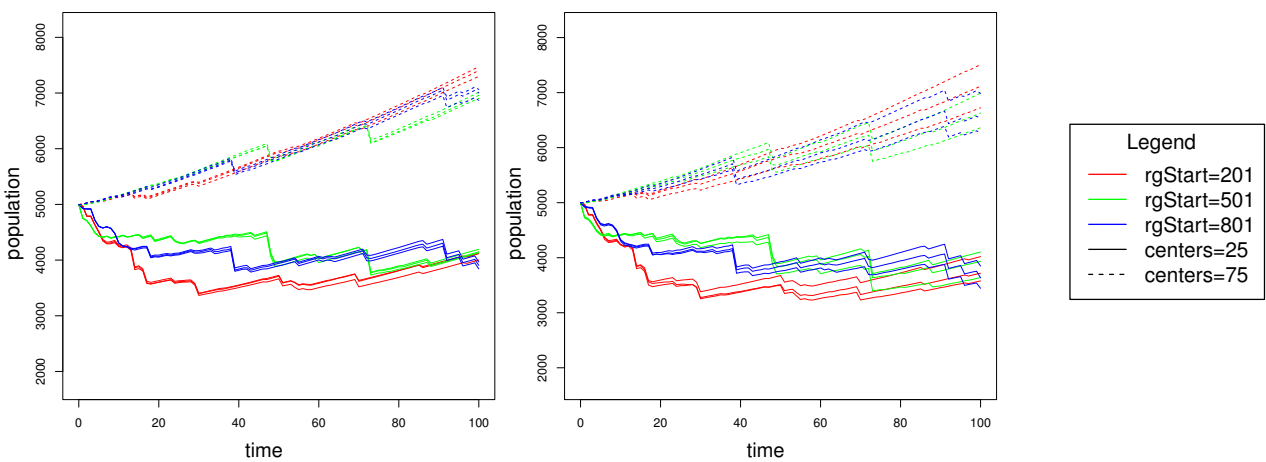

rgStart gives the flood sequences used for the simulation (201 for sequence 2, 501 for sequence 5, 801 for sequence 8 ).

Figure 2: Evolution of population (Benchmark on left, Insurance on right)
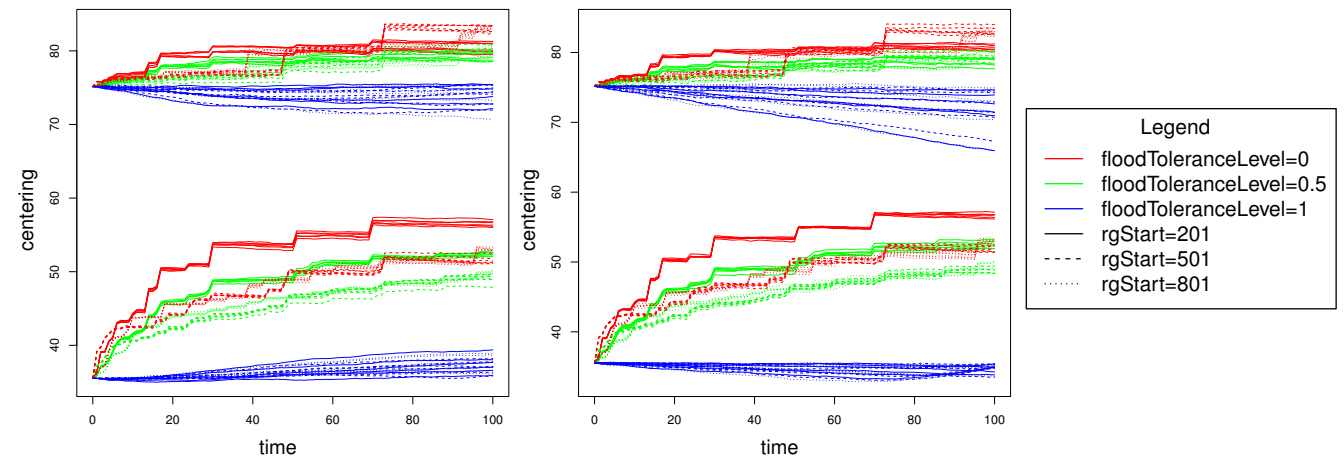

centers gives the mean location of the population at the beginning of the simulation. centers $=25$ is for a population very close to the river, centers $=75$ is for a population quite close to the river. The limit of flood prone area is 100 .

Figure 3: Evolution of the centering of installations (Benchmark on left, Insurance on right)
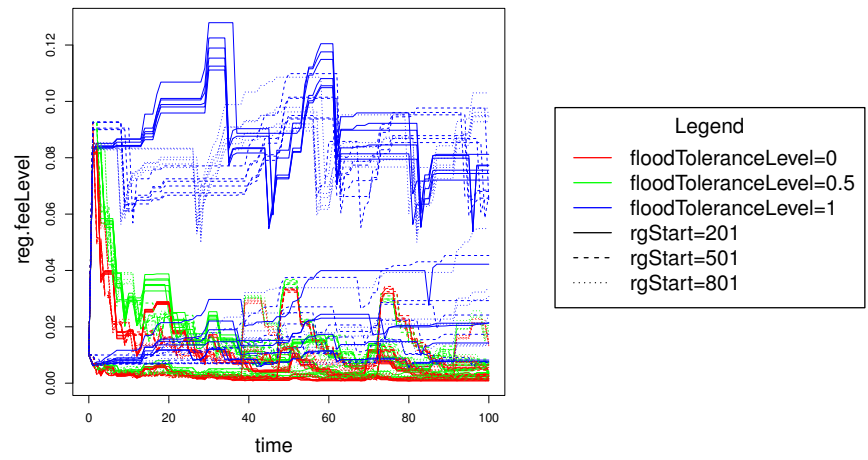

Figure 4: Evolution of rate 